\title{
Analysis of flooding in urban areas, taking into account the residence time of the water on site case of study: Veracruz, México
}

\author{
Faustino De Luna $C^{1, a}$, Oscar A. Fuentes $M^{1}$, Laura Vélez $M^{1}$ and Ismene L. A. Rosales Plascencia ${ }^{2}$ \\ ${ }_{2}^{1}$ Instituto de Ingeniería UNAM - Universidad Nacional Autónoma de México, Av. Universidad No.3000 Coyoacán, México D.F. \\ ${ }_{2}^{2}$ Universidad Autónoma Metropolitana Unidad Azcapotzalco, Azcapotzalco México D.F.
}

\begin{abstract}
Analysing some aspects of water management in urban areas affected by flooding, an event that occurred in September 2010 by overflows Cotaxtla Jamapa and rivers in western Mexico along with the rain event for five consecutive days. In this area, near the Gulf of Mexico, the elevations are less than three meters elevation.

Floods are common in cities like Veracruz, in this article the flood risk calculated by means of a hydraulic model of rainfall-runoff dimensional type developed at the Institute of Engineering of the National Autonomous University of Mexico. Data digital terrain elevation models of LIDAR were used, records hourly rainfall levels and channels of some hydrometric stations of the National Water Commission. The location of housing and services in a metropolitan area considered to calculate the depths of flooding in them.

To estimate the damage, shall take into account the hydrodynamic behaviour of the flows. Since houses remain flooded for several days, was the reason to use precipitation level for more than seven days. in the mathematical modelling of flows water with a regular grid made up of cells $10 \mathrm{~m}$ by side with the boundary condition downstream, corresponding to the predicted change in the average sea level.
\end{abstract}

\section{Objective}

Warning the repercussions of the residence time of water in the study area, also the damage caused to homes by floods.

\section{Study area and available information}

The basin of the Papaloapan River, occupies 41.11 $\%$ of the total land area of the state with an area of 28.636 $\mathrm{km}^{2}$, also provides most of freshwater discharge with approximately 44.829 million cubic meters per year, representing $42.28 \%$ of the total for the state. The determining hydrological river system for this region is the Papaloapan River basin, and secondarily the Actopan River, La Antigua and Jamapa.

The study area divided into two, the Papaloapan River basin and Jamapa River Basin

Jamapa River Basin is located between $18^{\circ} 45^{\prime}$ and $19^{\circ} 14^{\prime}$ north latitude and between $95^{\circ} 56^{\prime}$ and $97^{\circ} 17^{\prime}$ west length. (National Water Commission CONAGUA For its acronym in Spanish, 2005) It has an area approximately $3,929 \mathrm{~km}^{2}$, distributed entirely within the state of Veracruz. Figure 1.

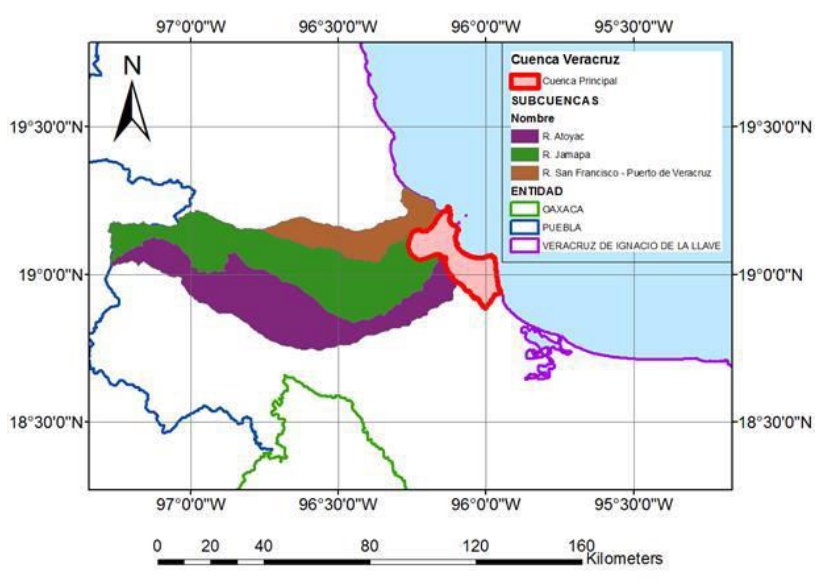

Figure 1. Location of the basin. Source: CONABIO, 2014

The state of Veracruz is an area of high rainfall; it has the largest volume of surface water discharged into the sea by rivers. Its main rivers are the Panuco (border with Tamaulipas) Tempoal and Tuxpan (part of the border with the State of Puebla), Cazones, Tecolutla, Nautla, Misantla, Actopan, La Antigua, Jamapa, Blanco, Papaloapan, Coatzacoalcos and Tonala. The river empties into the Gulf of Mexico in the town of Boca Del Rio, Veracruz.

\footnotetext{
a Corresponding author: FLunaC@iingen.unam.mx
} 


\section{Concepts}

Hydrology. To study the historic flooding in the basin of Jamapa river, data are daily rainfall of 29 weather stations, all in the state of Veracruz, daily data runoff of 2 hydrometric stations are located in the State of Veracruz, measuring runoff Cotaxtla and Jamapa rivers, which are shown in Figure 2

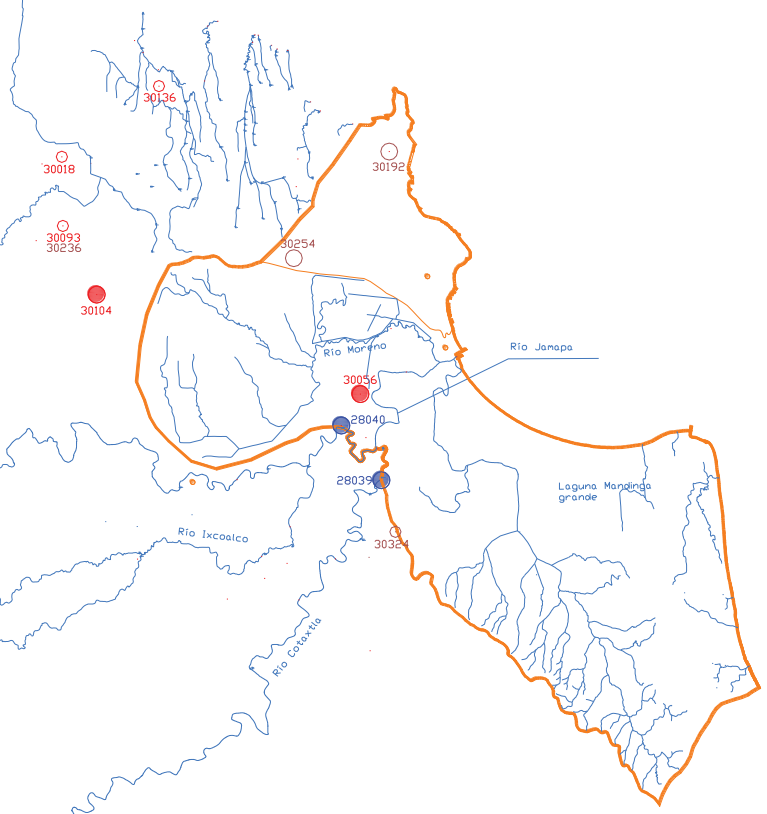

Figure 2. Location of weather stations and hydrometric

In The Paso del Toro station, on September 23, 1974, was recorded an average daily flow of $838.8 \mathrm{~m}^{3} / \mathrm{s}$, and hydrograph Figure 3 was obtained. Another important event was on July 29, 1972, El Tejar station.
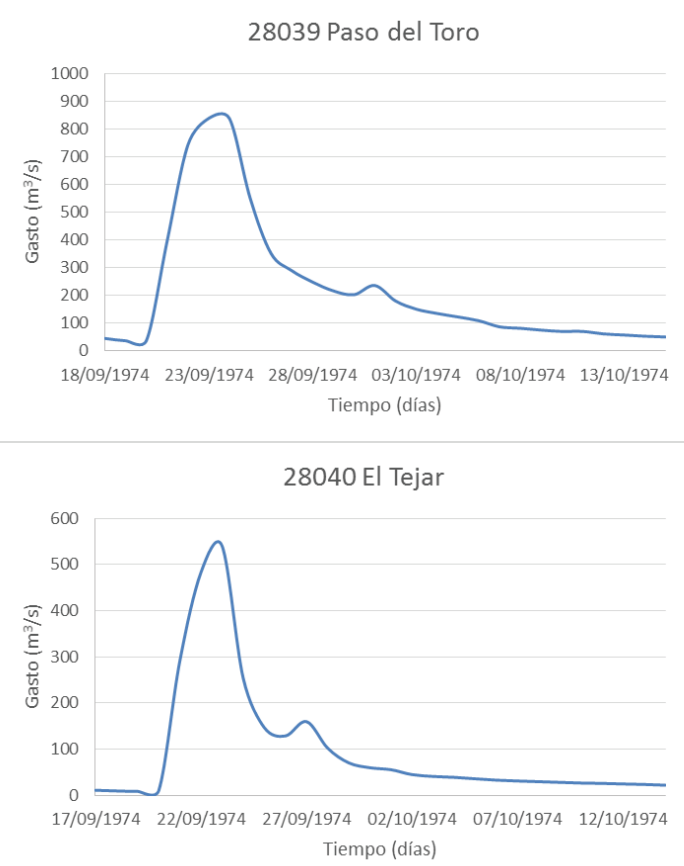

Figure 3 Hydrographs station of Paso Del Toro and El Tejar
Tropical cyclones that may have influenced the area are shown in Figure 4 and the results of the search for hydrometeorological events in the basin of river Jamapa too; information on three types of phenomena were distinguished:

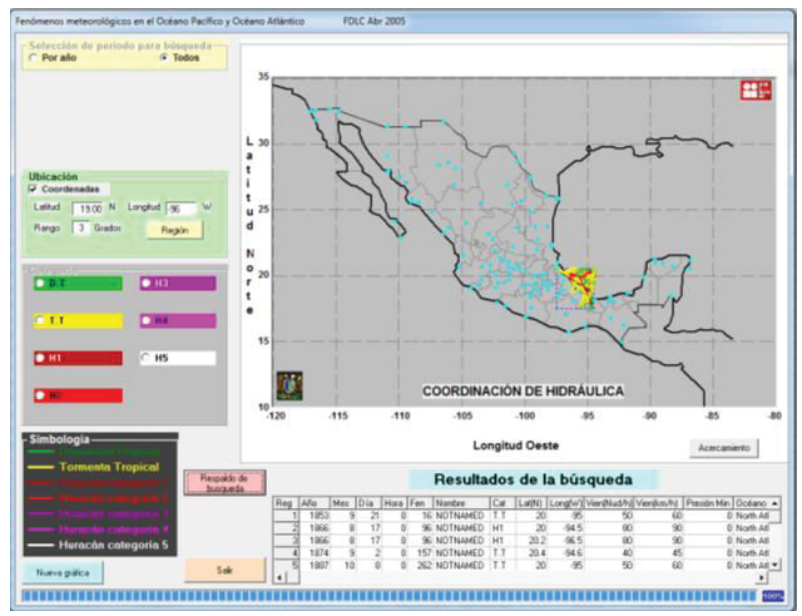

Figure 4.Searching events on the basin of interest

On October 3, 4 and 5, 2005, came Stan Hurricane, on this date the weather station 30056 (El Tejar) recorded the event as shown in Figure 5.
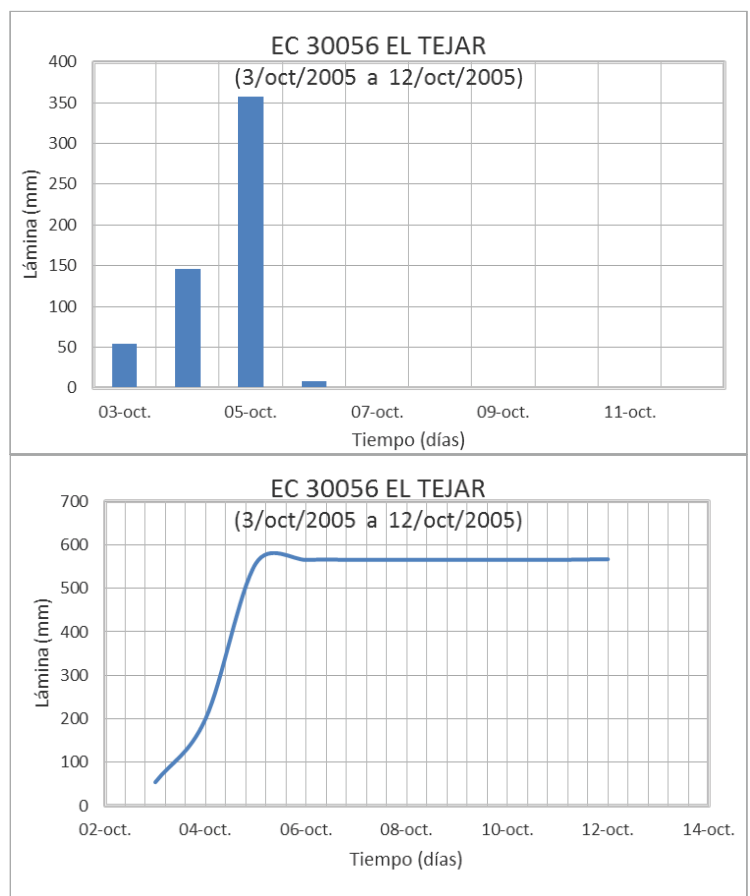

Figure 5. Hyetograph and mass curved station 300563

Hydrographs of Paso del Toro and El Tejar are very similar in shape and the magnitudes were as follows, 182 $\mathrm{m}^{3} / \mathrm{s}$ in El Tejar and $541 \mathrm{~m}^{3} / \mathrm{s}$ Paso Del Toro. Figure 6 . 

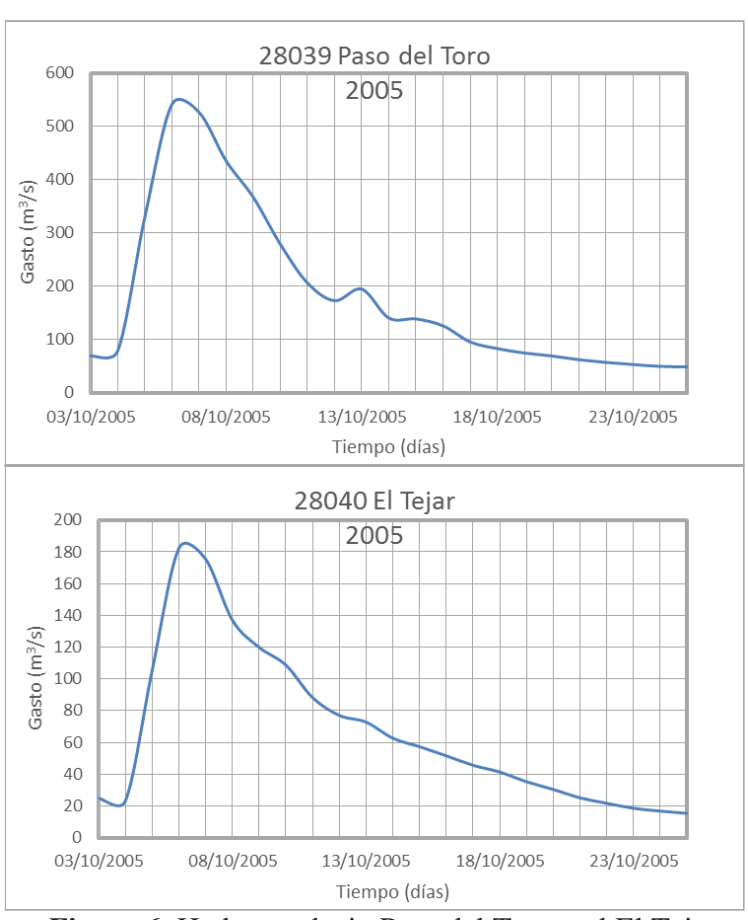

Figure 6. Hydrographs in Paso del Toro and El Tejar, October, 2005

In September 17, 2010 came Hurricane Karl, 3th Category, with winds of $120 \mathrm{~km} / \mathrm{h}$ causing flooding in several areas of Veracruz.

Figures 7 and 8 show the distribution of number of curve for the two basins, named Cotaxtla and Jamapa rivers.

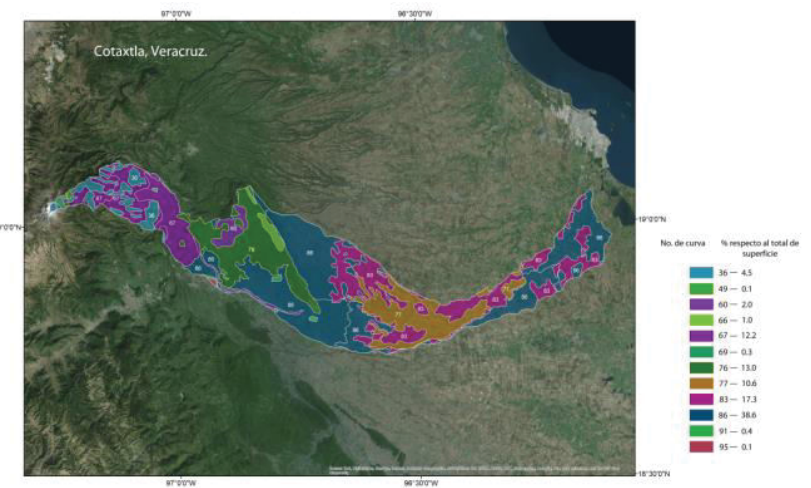

Figure 7. Distribution of curve numbers on the Cotaxtla River.

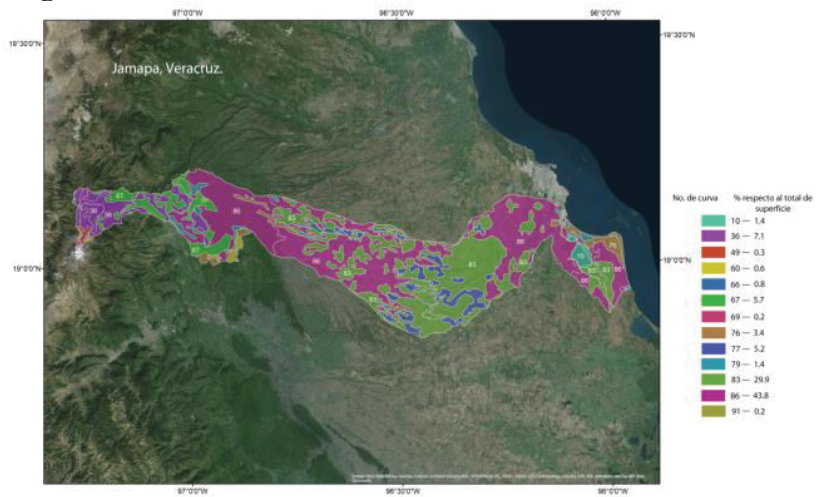

Figure 8. Distribution of curve numbers on the Jamapa River.

It was used to find the number of days, to be considered in the construction of hyetographs the power density spectra, and it was calculated with a computer program developed for this purpose, which uses the Fast Fourier Transform

It was decided that the rainy were 10 days. The values corresponding to the weather station and Mata Anona and El Tejar are shown in Figure 9.

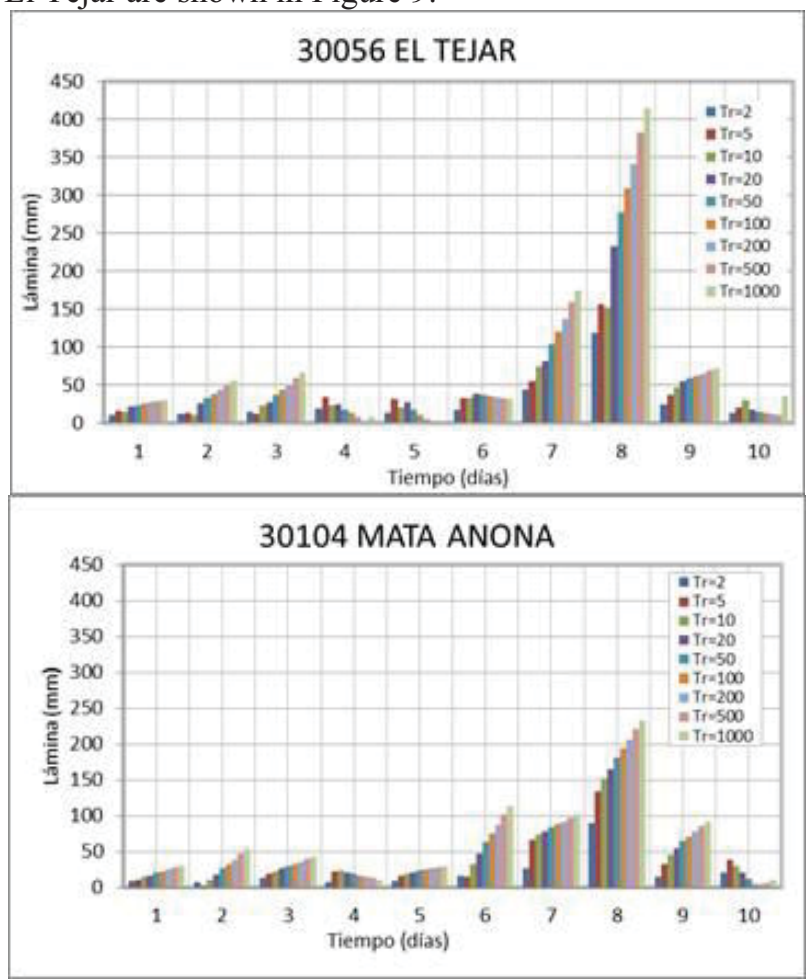

Figure 9. Hyetographs for different return periods of the Weather Station El Tejar and Mata Anona

The values corresponding to the Weather Station El Tejar and Mata Anona with simultaneity factors it's shown in the following. Figure 10.

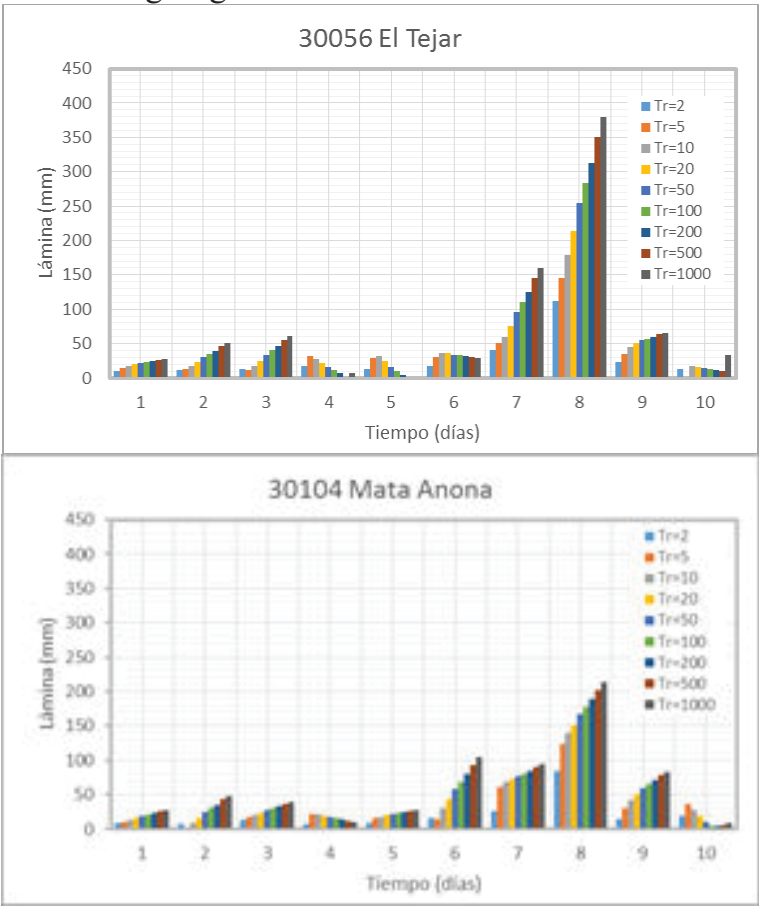

Figure 10. Hyetographs total rainfall $(\mathrm{mm})$ with simultaneity factor for different return periods. 
Applying the rain factors (Chen 1983) to each station, the ten days hyetographs are obtained with an hour bars, then the effective time hyetographs of rain are shown with simultaneity factor of extraordinary events for El Tejar and Mata Anona. Figure 11.

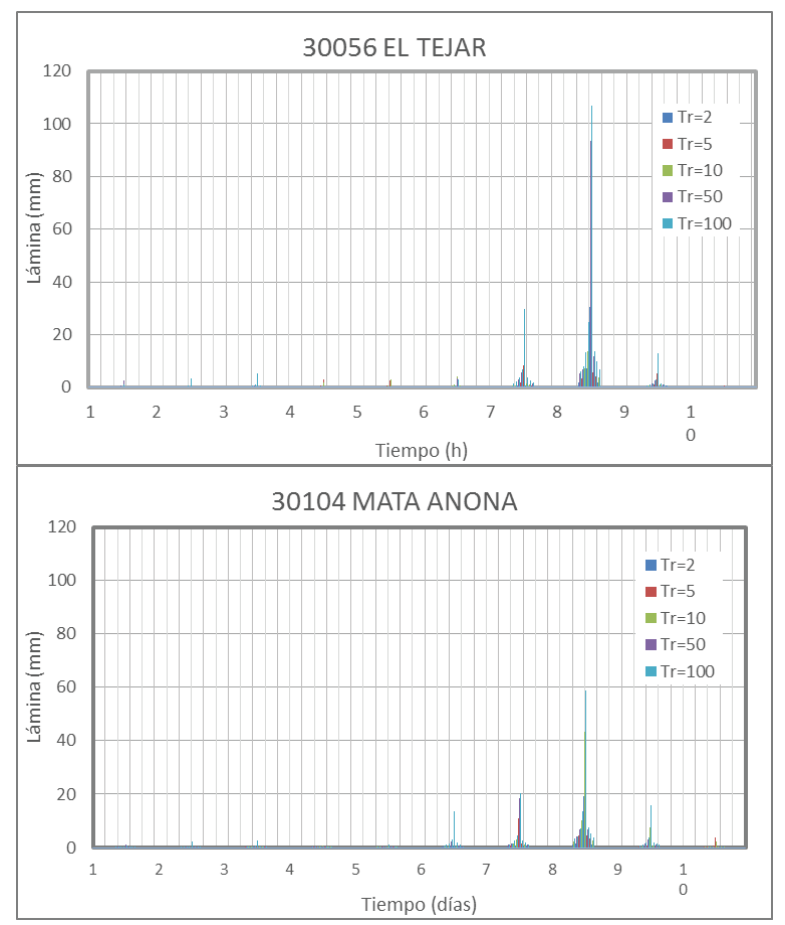

Figure 11. Hyetographs for different return periods, considering the time factor effective rainfall with concurrency of extraordinary events.

\section{Hydraulic mathematical model}

Phenomena distribution on a spatial continuous medium requires the description with magnitudes evaluated at every moment and in every point in space. Thus in models expressing the rate of change of the descriptive variables are the partial derivatives also take into account the spatial variation.

For certain kind of partial differential equations are known analytical solutions, but in general, it is necessary to find approximate solutions as much as possible or necessary, to the exact solutions (unknown). To calculate the flow of rain water on the ground are used for the conservation of momentum for a two-dimensional flow (Mahmood and Yevjevitch, 1975)

$$
\begin{aligned}
& \frac{\partial u}{\partial t}+u \frac{\partial u}{\partial x}+v \frac{\partial u}{\partial y}+g \frac{\partial h}{\partial x}=g\left(S_{x}-S_{f x}\right) \\
& \frac{\partial v}{\partial t}+u \frac{\partial v}{\partial x}+v \frac{\partial v}{\partial y}+g \frac{\partial h}{\partial y}=g\left(S_{y}-S_{f y}\right)
\end{aligned}
$$

Because changes in the water velocity on the ground are small, the derivatives of $\mathrm{u}$ and $\mathrm{v}$ with respect to $\mathrm{x}$ and $\mathrm{y}$ are eliminated the above equations, so that, by dividing the acceleration of gravity is

$$
\begin{aligned}
& \frac{1}{g} \frac{\partial u}{\partial t}+\frac{\partial h}{\partial x}=\left(S_{x}-S_{f x}\right) \\
& \frac{1}{g} \frac{\partial v}{\partial t}+\frac{\partial h}{\partial y}=\left(S_{y}-S_{f y}\right)
\end{aligned}
$$

For calculating the slopes of friction, it proposed the use of Manning Strickler formula

$$
\begin{aligned}
& S_{f x}=\frac{n^{2}|u| u}{h^{4 / 3}} \\
& S_{f y}=\frac{n^{2}|v| v}{h^{4 / 3}}
\end{aligned}
$$

If deemed to equations 5 and 6 in equations 3 and 4 we see that

$$
\begin{aligned}
& \frac{1}{g} \frac{\partial u}{\partial t}+\frac{n^{2}|u| u}{h^{4 / 3}}=-\frac{\partial h}{\partial x}-\frac{\partial z}{\partial x} \\
& \frac{1}{g} \frac{\partial v}{\partial t}+\frac{n^{2}|v| v}{h^{4 / 3}}=-\frac{\partial h}{\partial y}-\frac{\partial z}{\partial y}
\end{aligned}
$$

Equations 7 and 8 are equations describing the dynamics of momentum conservation whereas the flow takes place on a plain. The principle of conservation of mass in two dimensions horizontal is

$$
\frac{\partial h}{\partial t}+\frac{\partial}{\partial x} u h+\frac{\partial}{\partial y} v h=q
$$

Where $\mathrm{q}$ is the volume of effective rainfall that enters per unit time and unit area. This expression is also called continuity equation. To calculate the flow of water in a flood plain must solve the system of differential equations formed by the expressions 7,8 and 9 considering certain initial and boundary conditions.

As there is no analytical method for the solution of the equations above, to give an approximate solution of the same, we propose a method of finite differences.

For the application of the mathematical model were written several computer programs in Visual Basic language. The application of computer programs was exhaustive and it was necessary to simulate many possible options to define hydraulic conditions for various probabilities of occurrence overflow flooding rain river basin itself.

\subsection{Mathematical model results}

Giving an approximate solution has been proposed a finite difference method. The application of the mathematical model, several computer programs were written in Visual Basic.

The application of computer programs was exhaustive and that there was need to simulate many possible options to define hydraulic conditions for various probabilities of occurrence floods overflow rain river and basin itself

The inputs to the computer program were precipitation in each grid cell calculation every hour for 2 
specific days of a hydrological study and a mesh with specific terrain elevations for the area of interest.

\subsection{Digital elevation model}

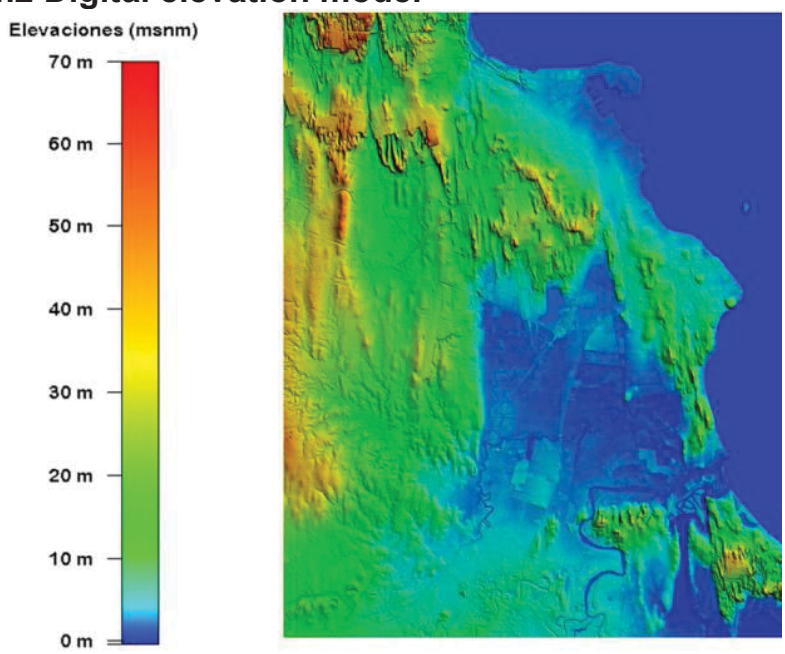

Figure 12. Digital elevation model in the study area

Although there is information with resolution between 5 and $10 \mathrm{~m}$, to carry out mathematical modeling, a digital elevation model with a resolution of $50 \mathrm{~m}$ by 50 $\mathrm{m}$ was used as it was considered that the resolution results were obtained with sufficient resolution and in a suitable mathematical calculation time. In addition, INEGI topographic maps were used (acronym of the National Institute of Geography and Statistics).

The mesh considered in the mathematical model 881 columns by 1,021 rows. To achieve numerical stability in mathematical modeling considering the cell size of $50 \mathrm{~m}$ by $50 \mathrm{~m}$ and taking into account that the slope is strong mostly considered the passage of time is 0.6 seconds.

With the results were drawn inundation areas and velocity areas in 48 hour modeling (Figures 13 and 14)

A resultant product from the mathematical modeling corresponds to the envelope of depths and maximum velocities for the entire simulation period, in other words, a map with maximum values, not necessarily from the same simulation time is obtained, the maximum values may occur at different times but the worst value considered is the maximum.

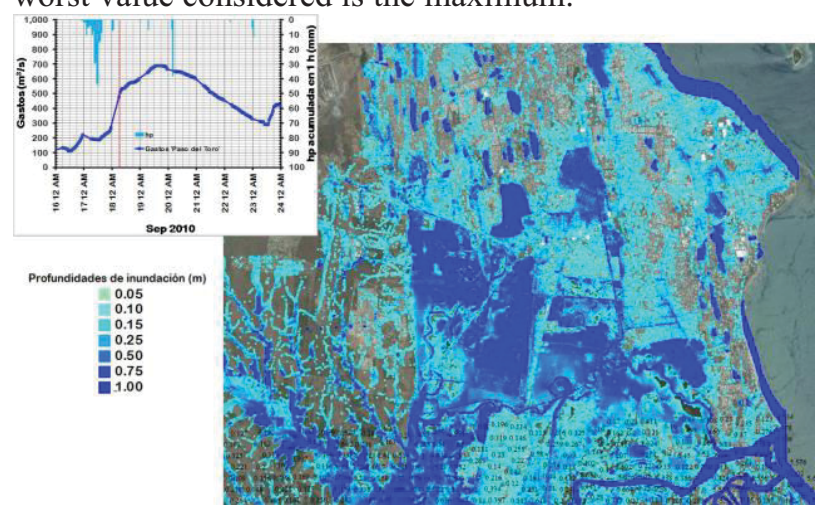

Figure 13. Satellite image with envelopes depths maximum values resulting from mathematical modeling in the historical event of 2010

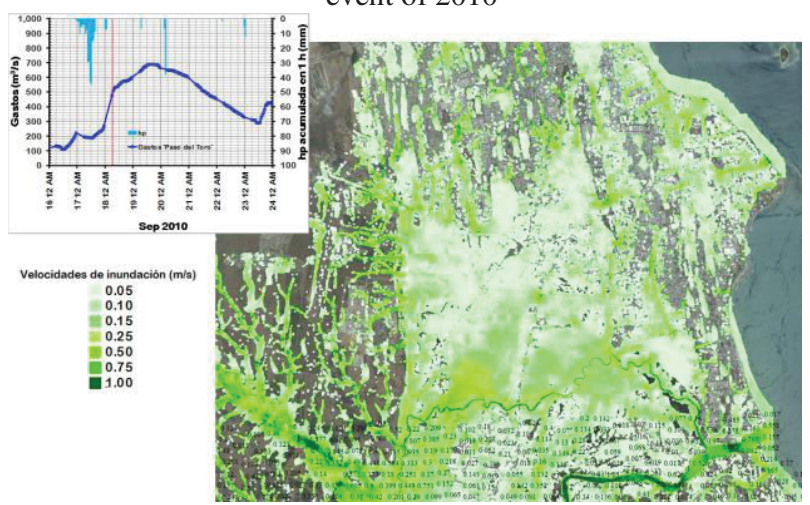

Figure 14. Satellite image with envelopes velocities maximum values resulting from mathematical modeling in the historical event of 2010

\section{Vulnerability and Severity}

Below presents the definition of vulnerability and vulnerability index.

Increasing depth and water speed, the damage increase. At higher speeds, the water has greater capacity to transport objects. The damage will be considerable if it erodes the riverbed and will depend on the magnitude of the force of impact. It has called vulnerability to the susceptibility of the houses were damaged when a threat of certain intensity occurs. (For the case study, the houses and their contents or furniture).

Vulnerability index is the proportion of the total cost of the damage to houses where some flooding occurs and is calculated as follows:

$$
D=I v C
$$

Where:

\section{Total cost of damage \\ IV Vulnerability index (between 0 y 1 )}

Risk: It is up to the expectation or expected value of losses, produced by the occurrence of a phenomenon of natural or anthropogenic origin, a particular physical or social entity set. (10 and 11)

The dictionary of the Royal Spanish Academy, says that risk means, contingency or proximity of damage (12).

$$
\mathrm{R}=\mathrm{E}(\mathrm{D})=\mathrm{p}_{1} \mathrm{D}_{1}+\mathrm{p}_{2} \mathrm{D}_{2}+\mathrm{p}_{3} \mathrm{D}_{3}+\cdots+\mathrm{p}_{\mathrm{n}} \mathrm{D}_{\mathrm{n}}=\Sigma \mathrm{pD}
$$

It was used for location of urban areas; topographic maps use scale 1:50,000 (INEGI Figure 15); the location of each house is obtained by INEGI as digital information. 


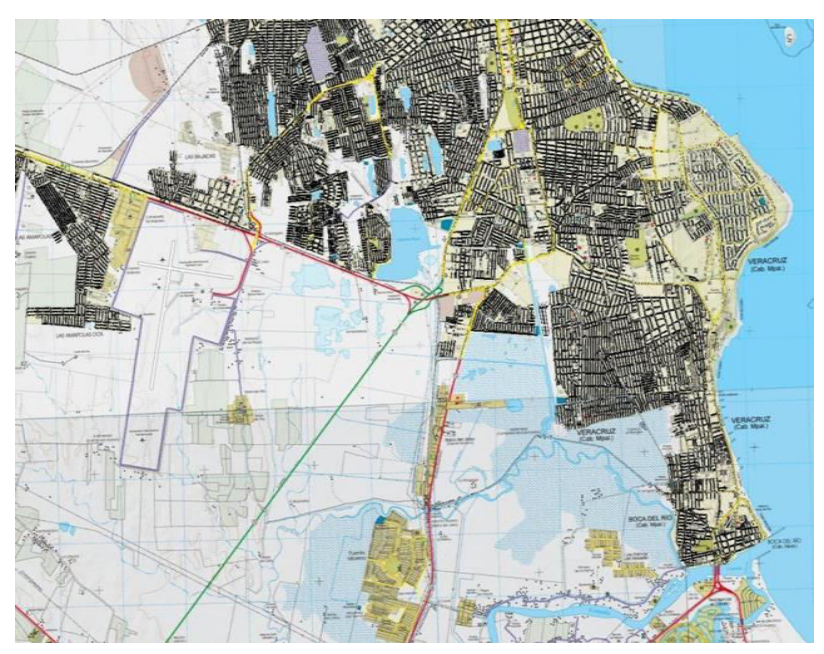

Figure 15. Vector information of houses locations.

To estimate the vulnerability functions for each kind of housing, CENAPRED proposes a number of configurations of furniture and household according to the Basic Guide for the State and Municipal Atlas Hazard and Risk, then the vulnerability curves are presented 5 types of houses, the figure 16 shows a type house I.

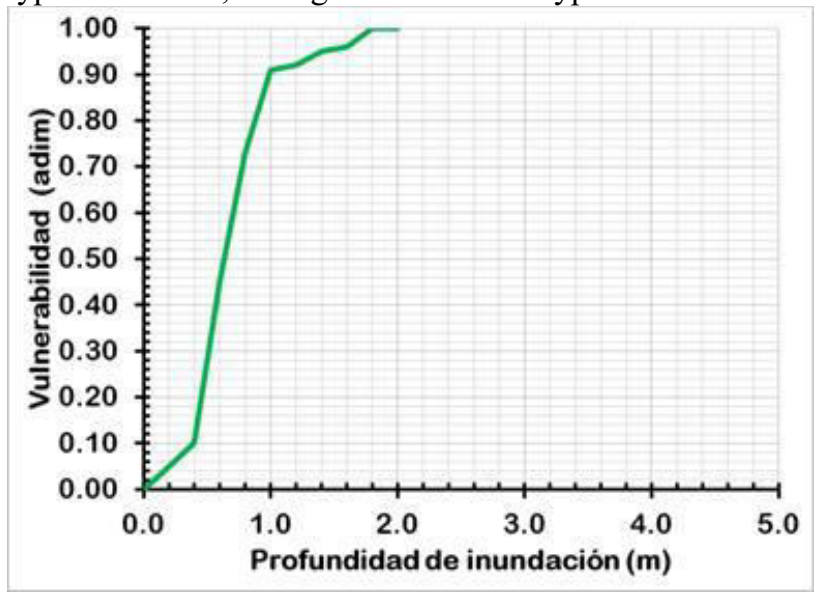

Figure 16. Home vulnerability function for type I

Damage to the analysis, It has been identified 5 types of houses in the urban area of Veracruz, as shown below in Figure 17. Calculating the cost of content and cost furniture. The graphic types are from I, II and III reach a depth of two meters because they are single-level homes, not houses type IV and V that are houses with two or more levels.

The graphs of cost it was initially obtained from a graphical base, from more than 400 nationwide surveys. Simultaneously it was obtained a market study that, developed in the which the market value of the homes in the area, also the value per $\mathrm{m}^{2}$ of building area under study and surrounding towns within the state, were identified obtaining the likely cost of flood damage, Finally curves were adjusted according to the type of house.

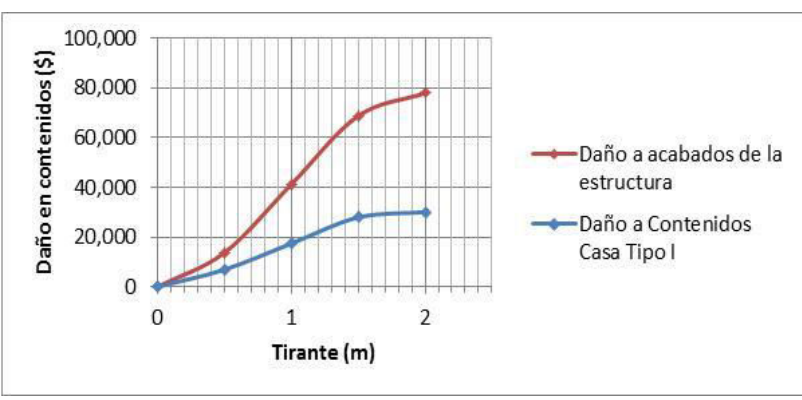

Figure 17. Graph of cost against flood depth, for a household type I

The analysis procedure is performed by the coordinate data for each house, its respective dimension of land and water elevation at that point for each return period, obtaining a value for each of these.

\subsection{Severity maps}

In December 2007, the government of New South Wales (Australia) requested a study Bielsdown River, which passes through a town called Dorrigo in order to determine an appropriate risk management in the floodplain.

This study was conducted to define the levels and velocity of flood, Tool that was decided to use for the present study. Figure 18 shows valuable data regarding flow "velocity/hydraulic flood depth" (resistance to tipping the walls of the houses).Considering this concept; we have named the product severity as shown.

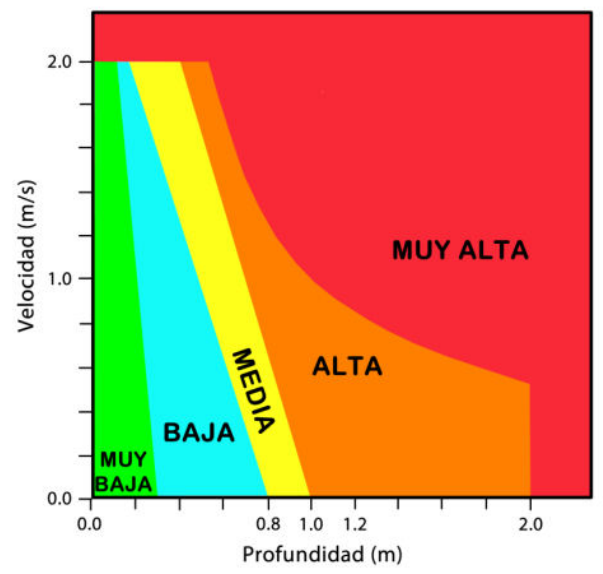

Figure 18 Color scale

Thus, with maximum depths and certain maximum speeds, by considering the graph in Figure 18, it can be obtained maps of severity, where the color scale indicates in red the worst option. Severity maps for each return periods analyzed are presented in the following figure 19. 


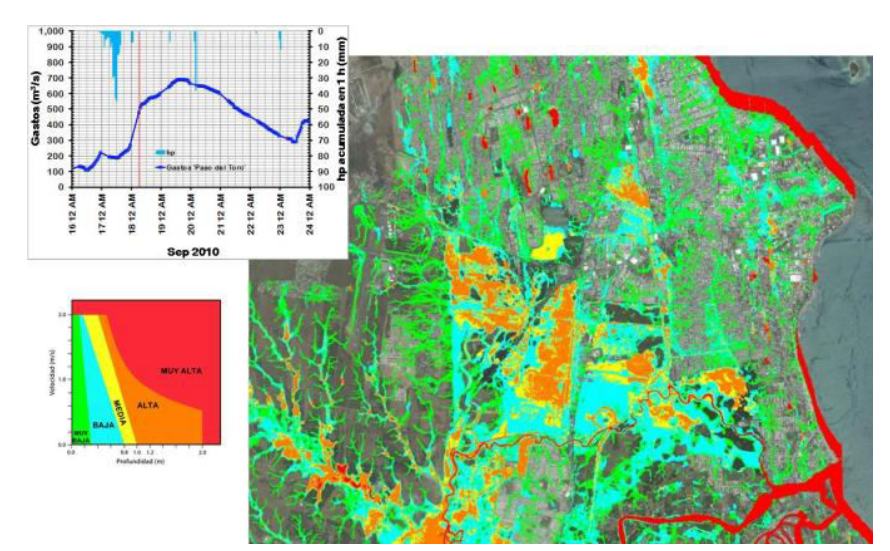

Figure 19. Severity

Finally, on the study area as shown in Figure 20 obtained the Expected Annual Damage.

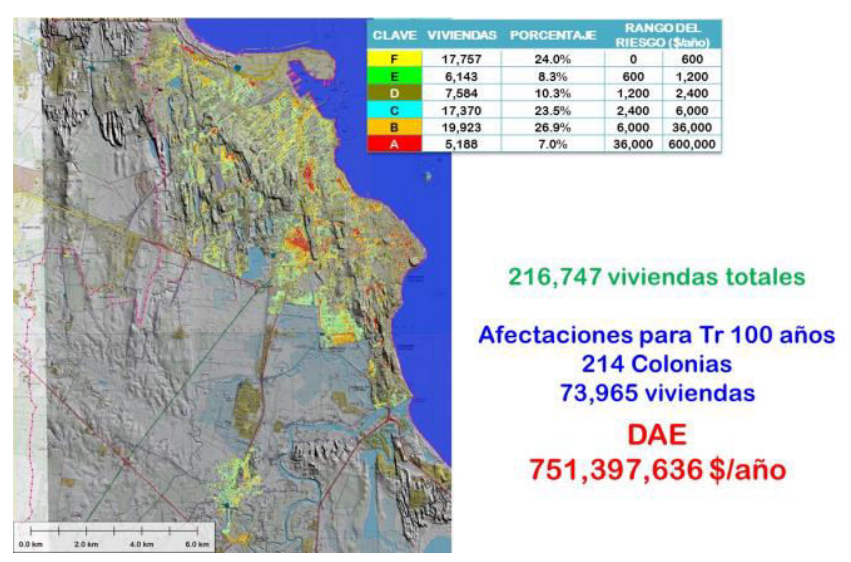

Figure 20. Expected Annual Damage

\section{Conclusions}

Flooding in the lower part of the basin is generated by the overflowing of rivers, due to runoff in the upper area in the basin, the result of extreme rainfall by the presence of weather events, such as tropical cyclones and cold fronts, the rain produces, in the lower area, not drained efficiently, and when the Jamapa leads an important river flow due to the slope of the terrain.

Not necessarily, the works that are constructed reduce flood damages. Sometimes the water that temporarily occupied an area of land can be moved to other regions where it could cause further injury; therefore, it is convenient to carry out comprehensive studies of a whole watershed to evaluate the goodness of the proposed works, usually with simulation surface flow models covering the basin where flood areas are located.

\section{References}

1. Baeza, R. C. (2007). "Estimación regional de factores de convectividad para el cálculo de las relaciones intensidad-duración-frecuencia”. Tesis de Maestría. Universidad Nacional Autónoma de México.

2. Baró, Suarez José Emilio. “Costo más probable de daños por inundación en zonas habitacionales de México", septiembre 2011.

3. Chen, C. L. (1983). Rainfall Intensity-DurationFrequency Formulas. Journal of Hydraulic Engineering, ASCE, Vol. 109, No. 12, December 1983, pp. 1603-1621.

4. Chow, V. T. (1994). "Hidrología Aplicada". McGraw-Hill Interamericana, S.A., Colombia.

5. CENAPRED, (2004).”Guía Básica para la elaboración de Atlas Estatales y Municipales de Peligros y Riesgos", 1a Edición Diciembre 2004.

6. Fuentes, M. O. A. (2012). “Obtención de hietogramas correspondientes a diferentes periodos de retorno", XXV Congreso Latinoamericano de Hidráulica, San José, Costa Rica.

7. Maidment, D. R. (1993). Handbook of Hydrology. McGraw-Hill Inc., USA.

8. Metodología para la Elaboración de Mapas de Riesgo por Inundaciones en Zonas Urbanas. Centro Nacional de Prevención de Desastres. Serie: Atlas Nacional de Riesgos. Fenómenos Hidrometeorológicos. Marco Antonio Salas, Julio 2011.

9. OMM, Gestión Integrada de Crecidas: Documento Comceptual. Organización Meteoorológica Mundial. OMM-No.1047. Ginebra, Suiza 2009.

10. OMM, Tercera Conferencia Mundial sobre el clima, Ginebra, Suiza, 31 de agosto-4 de septiembre de 2009.

11. Paoli, Carlos U. Curso Gestión Integrada de Crecidas, Facultad de Ingeniería y Ciencias HídricasUniversidad Nacional del Litoral. Centro Regional Litoral-Instituto Nacional del Agua.-Prof. Ing. Carlos U. Paoli, Santa Fe Argentina, 26 al 30 de abril de 2010. 